\title{
Ouabain-Induced Cell Proliferation in Cultured Rat Astrocytes
}

\author{
Yosuke Murata, Toshio Matsuda, Kazuko Tamada, Rie Hosoi ${ }^{\# 1}$, Shoichi Asano, Kazuhiro Takuma ${ }^{\# 2}$, \\ Koh-ichi Tanaka ${ }^{\# 3}$ and Akemichi Baba* \\ Department of Pharmacology, Faculty of Pharmaceutical Sciences, Osaka University, 1-6 Yamada-oka, Suita, Osaka 565, Japan
}

Received August 27, 1996 Accepted September 26, 1996

\begin{abstract}
Ouabain markedly stimulated not only $\left[{ }^{3} \mathrm{H}\right]$ thymidine incorporation but also $\left[{ }^{3} \mathrm{H}\right]$ uridine incorporation into astrocytes. The effects were observed at $36-48 \mathrm{hr}$ and $12-72 \mathrm{hr}$ after addition of ouabain, respectively. The dose-response curves were both bell-shaped types with a peak at $10^{-3} \mathrm{M}$ for thymidine incorporation and $2 \times 10^{-3} \mathrm{M}$ for uridine incorporation. Ouabain increased cell number as determined by an assay using 3-(4,5-dimethylthiazol-2-yl)-2,5-diphenyl tetrazolium bromide and by a method using a hemocytometer. Low concentration of external $\mathrm{K}^{+}$mimicked the effect of ouabain in stimulating $\left.{ }^{3} \mathrm{H}\right]-$ thymidine incorporation, and high concentration of external $\mathrm{K}^{+}$blocked the effect of ouabain. In contrast to astrocytes, ouabain did not stimulate $\left[{ }^{3} \mathrm{H}\right]$ thymidine incorporation into $\mathrm{C} 6$ glioma and fibroblast cells. The effect of ouabain on $\left[{ }^{3} \mathrm{H}\right]$ thymidine incorporation in astrocytes was dependent on external $\mathrm{Ca}^{2+}$, and it was blocked by cycloheximide. These findings indicate that prolonged $\mathrm{Na}^{+}, \mathrm{K}^{+}$-ATPase inhibition causes cell proliferation in cultured astrocytes in cell-specific and $\mathrm{Ca}^{2+}$-dependent manners.
\end{abstract}

Keywords: Ouabain, $\mathrm{Na}^{+}, \mathrm{K}^{+}$-ATPase, Cell proliferation, Thymidine incorporation, Astrocyte

Previous studies show that ouabain-like factors that may serve as in vivo regulators of the $\mathrm{Na}^{+}, \mathrm{K}^{+}$-ATPase activity are present in animal brain tissues $(1,2)$. Ouabain-like factors are considered to have an important role in hypertension and natriuresis (3-6). Consistent with the role of ouabain-like factors, exogenous ouabain acted centrally to cause sympathoexcitation and hypertension $(7-10)$. In addition, injection of ouabain into the specific regions of rat brain produced a necrotic lesion $(11-13)$. These in vivo effects may be due to ouabaininduced inhibition of the $\mathrm{Na}^{+}, \mathrm{K}^{+}$-ATPase in the brain, although the exact mechanism is not known. Since the $\mathrm{Na}^{+}, \mathbf{K}^{+}$-ATPase is localized not only in neurons but also in glial cells, the possibility must be considered that glial cells as well as neurons are involved in the central effects of ouabain-like factors or exogenous ouabain.

We have previously demonstrated that $\alpha_{1^{-}}$and $\alpha_{2^{-}}$

\footnotetext{
${ }^{\# 1}$ Present address: Department of Medical Physics, Faculty of Medicine, Osaka University, 2-2 Yamada-oka, Suita, Osaka 565, Japan

${ }^{\# 2}$ Present address: Department of Analytical Chemistry, Faculty of Pharmaceutical Sciences, Kobe Gakuin University, Nishi-ku, Kobe 651-21, Japan

${ }^{\# 3}$ Present address: Department of Pharmacology, Kagoshima University Dental School, Kagoshima 890, Japan

* To whom correspondence should be addressed.
}

isoforms of the $\mathrm{Na}^{+}, \mathrm{K}^{+}$-ATPase are present in cultured rat astrocytes, and the former isoform is selectively induced by an activation of insulin-like growth factor-I (IGF-I) receptors (14). Furthermore, we found that ouabain (1 $\mathrm{mM}$ for $24 \mathrm{hr}$ ) blocked the mitogenic effect of IGF-I in astrocytes (15), suggesting the involvement of the $\alpha_{1}$-isoform in the mitogenic action of the growth factor in astrocytes. During the study, we unexpectedly observed that prolonged exposure of astrocytes to ouabain (1 mM for more than $36 \mathrm{hr}$ ) markedly stimulated $\left[{ }^{3} \mathrm{H}\right]-$ thymidine incorporation into the DNA fraction. That is, $\mathrm{Na}^{+}, \mathrm{K}^{+}$-ATPase inhibition for a restricted time blocks IGF-I-induced cell proliferation, while inhibition for a longer time stimulates $\left[{ }^{3} \mathbf{H}\right]$ thymidine incorporation in cultured astroyctes. This paper characterizes the ouabaininduced cell proliferation in cultured rat astrocytes.

\section{MATERIALS AND METHODS}

\section{Materials}

Cycloheximide and ouabain were obtained from Sigma Chemical Co. (St. Louis, MO, USA). $\left[{ }^{3} \mathrm{H}\right]$ Thymidine and $\left[{ }^{3} \mathrm{H}\right]$ uridine were obtained from Amersham Japan (Tokyo). Fetal calf serum (FCS) was from Hazleton Biologics (Lenexa, KS, USA). All other chemicals used were of the highest purity commercially available. 


\section{Cell cultures}

Relatively pure cultures of polygonal astroglial cells were prepared from cerebral cortices of 1-day-old Sprague-Dawley rats (Japan SLC, Inc., Shizuoka) as previously reported (16). In brief, cells were cultured in Eagle minimum essential medium (MEM) containing $10 \% \mathrm{FCS}$ and $2 \mathrm{mM} \mathrm{L-glutamine}$ at $37^{\circ} \mathrm{C}$. After the cells became confluent (10-20 days), the secondary cultures (seeded at $2 \times 10^{4}$ cells per well) were grown in complete medium until subconfluence (usually 14-20 days). The subconfluent astrocytes used here consisted of more than 95\% flat polygonal astrocytes (type-1 astrocytes), as confirmed by phase contrast microscopy and positive immunostaining with anti-glial fibrillary acidic protein antibody $(14,16)$, and it did not contain neurons as assessed by negative immunostaining with $\mathrm{Na}^{+}, \mathrm{K}^{-}$-ATPase $\alpha_{3}-$ isoform antibody.

Fibroblasts were cultured from the meninges of the same neonatal rats used for the culturing of astrocytes as reported previously (17). Rat $\mathrm{C} 6$ glioma cells were grown in MEM containing $10 \% \mathrm{FCS}$ and $2 \mathrm{mM}$ L-glutamine as reported previously (18).

\section{Cell viability}

The number of surviving cells was measured by a colorimetric assay using 3-(4,5-dimethylthiazol-2-yl)-2,5diphenyl tetrazolium bromide (MTT) and by the previously reported hemocytometer method (14).

\section{$D N A$ and RNA syntheses}

DNA synthesis was determined by measuring $\left[{ }^{3} \mathrm{H}\right]-$ thymidine incorporation as reported previously (14). In brief, the cells in 24-well plates were preincubated in FCS-free MEM for $24 \mathrm{hr}$ and incubated with ouabain for $48 \mathrm{hr}$ in FCS-free MEM. [ $\left.{ }^{3} \mathrm{H}\right]$ Thymidine (18.5 kBq/well) was added to the cultures for the last $24 \mathrm{hr}$ of incubation. Then, the cells were washed and treated with trichloroacetic acid. The trichloroacetic acid-insoluble fraction was dissolved with $1 \mathrm{~N} \mathrm{NaOH}$ for the radioactivity and protein assays. RNA synthesis was determined by measuring $\left[{ }^{3} \mathrm{H}\right]$ uridine incorporation: the method was the same as that for $\left[{ }^{3} \mathrm{H}\right]$ thymidine incorporation except that $\left[{ }^{3} \mathrm{H}\right]-$ thymidine was replaced with $\left[{ }^{3} \mathrm{H}\right]$ uridine. In the time course experiments, $\left[{ }^{3} \mathrm{H}\right]$ thymidine and $\left[{ }^{3} \mathrm{H}\right]$ uridine were added for the last $3 \mathrm{hr}$ of incubation. The incorporation (radioactivity per protein) was expressed as a percentage of the control. Controls in $\left[{ }^{3} \mathrm{H}\right]$ thymidine and $\left[{ }^{3} \mathrm{H}\right]$ uridine incorporation were about $15 \times 10^{4}$ and $20 \times 10^{4} \mathrm{dpm} / \mathrm{mg}$ protein, respectively.

\section{RESULTS}

\section{Stimulation by ouabain of astrocyte proliferation}

Figure 1 shows the effect of ouabain on $\left[{ }^{3} \mathrm{H}\right]$ thymidine and $\left[{ }^{3} \mathrm{H}\right]$ uridine incorporation into DNA and RNA in the absence of FCS. Ouabain stimulated $\left[{ }^{3} \mathbf{H}\right]$ thymidine incorporation into DNA at concentrations of $10^{-4} \mathrm{M}$ to $10^{-3} \mathrm{M}$, and the effect was reduced progressively at con-
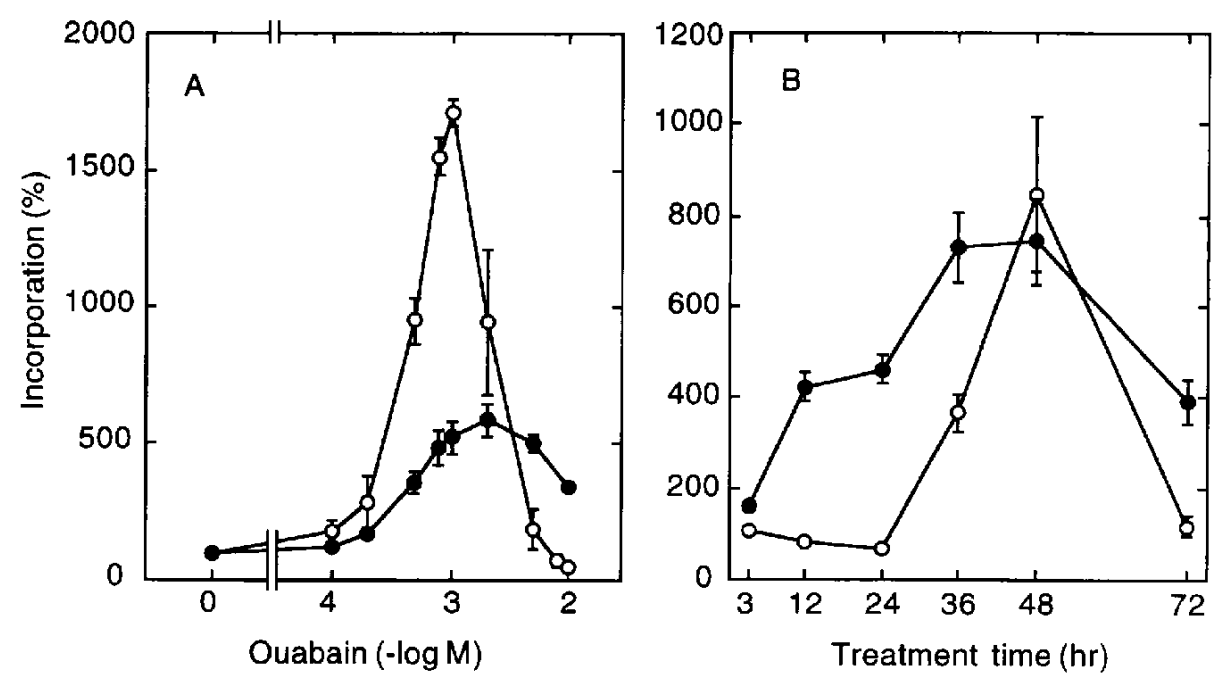

Fig. 1. Effect of ouabain on $\left[{ }^{3} \mathrm{H}\right]$ thymidine and $\left[{ }^{3} \mathrm{H}\right]$ uridine incorporation into cultured rat astrocytes. A: The cells were incubated with ouabain at the indicated concentrations for $48 \mathrm{hr}$ in FCS-free MEM. $\left[{ }^{3} \mathrm{H}\right]$ Thymidine $(O)$ and $\left[{ }^{3} \mathrm{H}\right]$ uridine $(O)$ were added $24 \mathrm{hr}$ after ouabain. Results shown as percentage of the value without ouabain are the means \pm S.E.M. of $4-12$ wells. B: The cells were incubated with $1 \mathrm{mM}$ ouabain for the indicated times in FCS-free MEM. [ $\left.{ }^{3} \mathrm{H}\right]$ Thymidine $(\bigcirc)$ and $\left.{ }^{3} \mathrm{H}\right]$ uridine (O) were added in the last $3 \mathrm{hr}$ of incubation. Results shown as percentage of the value at $3 \mathrm{hr}$ incubation without ouabain are means \pm S.E.M. of $10-12$ wells. 

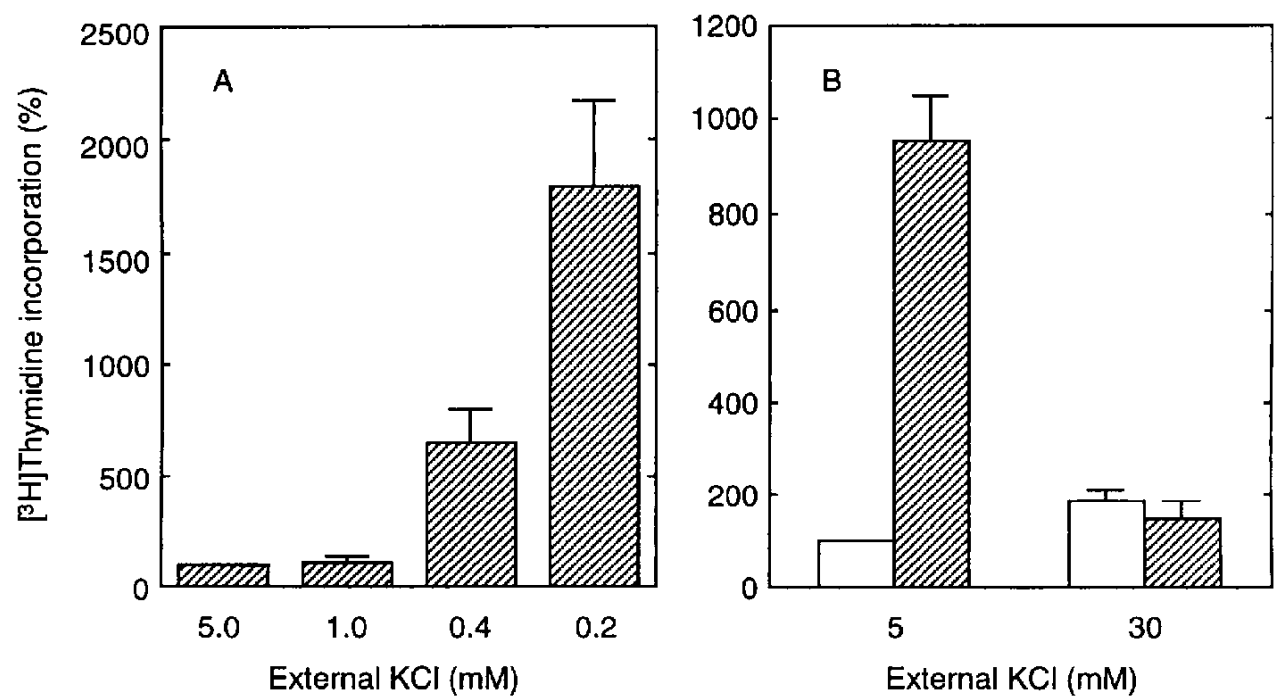

Fig. 2. Effect of extracellular $\mathrm{K}^{-}$on $\left.{ }^{3} \mathrm{H}\right]$ thymidine incorporation into cultured astrocytes. A: The cells were incubated in FCS-free MEM containing KCl at the indicated concentrations for $48 \mathrm{hr}$. Results shown as percentage of the value at $5 \mathrm{mM} \mathrm{KCl}$ are means \pm S.E.M. of $8-9$ wells. B: The cells were incubated in the absence (open column) or presence (hatched column) of 0.5 $\mathrm{mM}$ ouabain for $48 \mathrm{hr}$ in FCS-free MEM containing the indicated concentrations of KCl. Results shown as percentage of the value at $5 \mathrm{mM} \mathrm{KCl}$ without ouabain are means $\pm S$.E.M. of 8 wells.

centrations higher than $2 \times 10^{-3} \mathrm{M}$ : the apparent inhibitory effect of ouabain was observed at the concentration of $10^{-2} \mathrm{M}$. The effect of ouabain on RNA synthesis was slightly different from that of ouabain on DNA synthesis with regards to the dose-response curve (Fig. 1A) and time course (Fig. 1B). In addition, the effect of ouabain at $10^{2} \mathrm{M}$ was less in the case of $\left[{ }^{3} \mathrm{H}\right]$ uridine incorporation than in that of $\left[{ }^{3} \mathrm{H}\right]$ thymidine incorporation. The effect of ouabain on $\left[{ }^{3} \mathrm{H}\right]$ thymidine incorporation into DNA was antagonized by a high concentration of external $\mathrm{K}^{+}$and mimicked by a low concentration of external $\mathrm{K}^{+}$(Fig. 2). MTT assay and direct cell counting using a hemocytometer showed that ouabain treatment caused an increase in cell number; The dose-response curve was similar to that of ouabain-induced stimulation of $\left[{ }^{3} \mathrm{H}\right]$ thymidine incorporation into DNA (Fig. 3), but the degree of stimulation of $\left[{ }^{3} \mathrm{H}\right]$ thymidine incorporation into DNA was much higher than that of the increase in cell number.
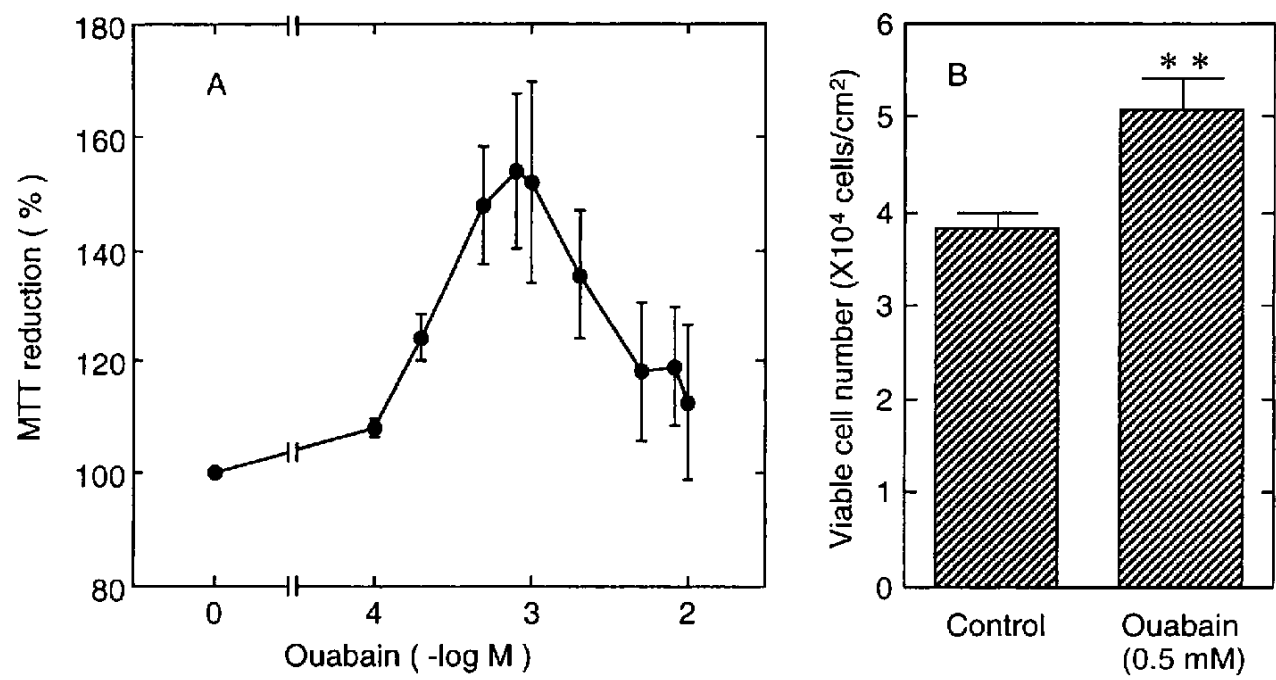

Fig. 3. Effect of ouabain on cell viability of cultured astrocytes. The cells were incubated with ouabain at the indicated concentrations for $48 \mathrm{hr}$, and MTT assay (A) and cell number (B) counting were carried out. Results are means \pm S.E.M. of 5-8 wells. ${ }^{* *} \mathrm{P}<0.01$, compared with control (Student's $t$-test). 


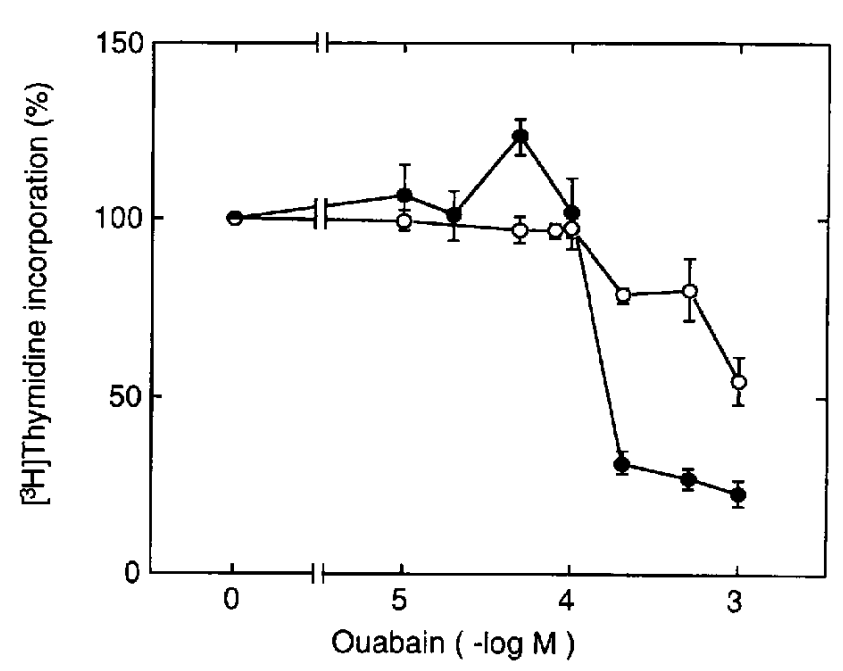

Fig. 4. Effect of ouabain on $\left[{ }^{3} \mathrm{H}\right]$ thymidine incorporation into $\mathrm{C6}$ glioma and fibroblast cells. Cultured $\mathrm{C} 6$ glioma $(O)$ and rat fibroblast (O) cells were incubated with ouabain at the indicated concentrations in FCS-free MEM for $48 \mathrm{hr}$. Results shown as percentage of the value without ouabain are means \pm S.E.M. of $5-8$ wells.

\section{Cell specificity for ouabain-stimualted DNA synthesis}

The effect of ouabain was cell-specific: ouabain inhibited $\left[{ }^{3} \mathrm{H}\right]$ thymidine incorporation into DNA in C6 glioma and fibroblast cells (Fig. 4), although FCS stimulated the incorporation in these cells (data not shown).

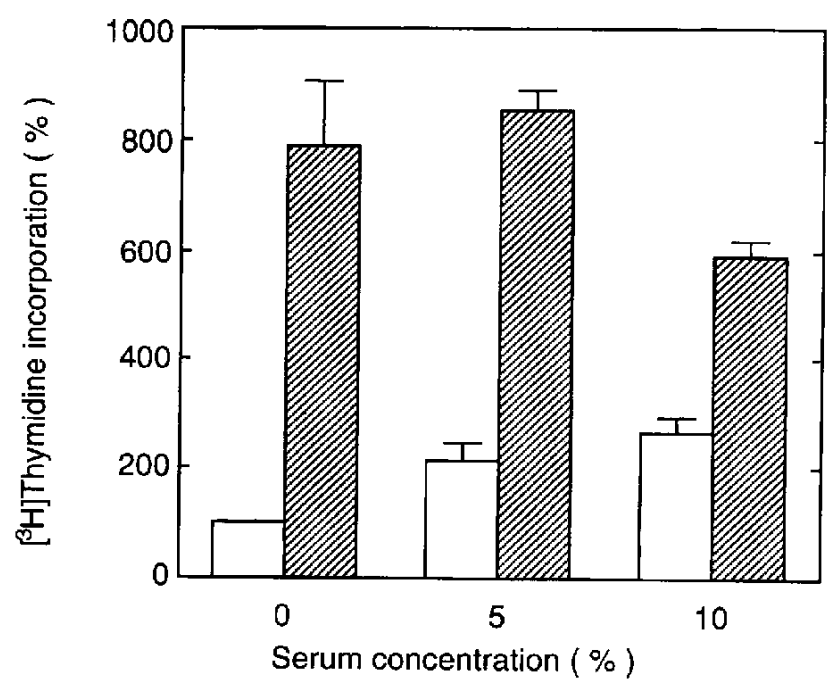

Fig. 5. Effects of ouabain and serum on $\left[{ }^{3} \mathrm{H}\right]$ thymidine incorporation into astrocytes. The cells were incubated with (hatched) or without (open) $1 \mathrm{mM}$ ouabain in MEM containing the indicated concentrations of FCS. Results shown as percentage of the value without ouabain and serum are means \pm S.E.M. of 8 wells.

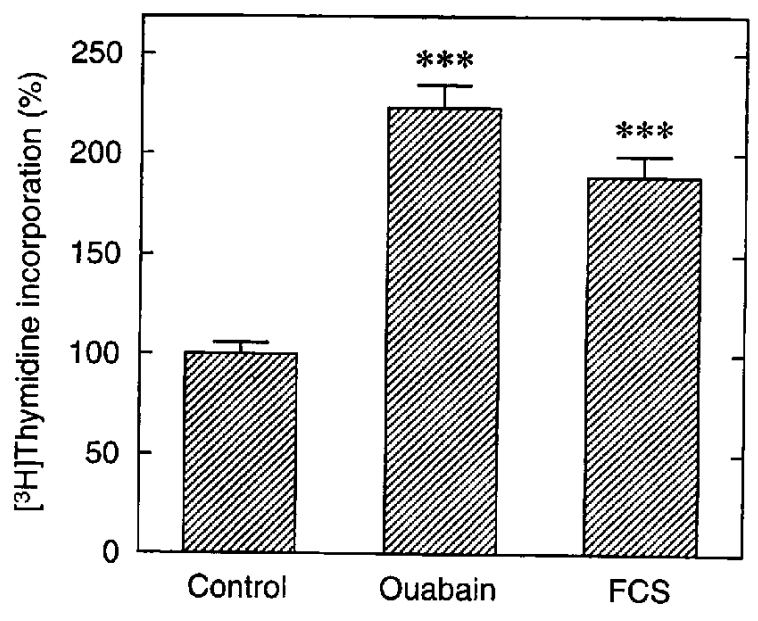

Fig. 6. Effect of ouabain on DNA synthesis in astrocytes preloaded with $\left[{ }^{3} \mathrm{H}\right]$ thymidine. The cells were incubated with $\left[{ }^{3} \mathrm{H}\right]$ thymidine for $1 \mathrm{hr}$ in FCS-free MEM and washed. The preloaded cells were incubated with $1 \mathrm{mM}$ ouabain or $10 \%$ serum for $48 \mathrm{hr}$. Results (shown as percentage of the value without ouabain and serum) are means \pm S.E.M. of 8 wells. ${ }^{* * *} \mathrm{P}<0.001$, compared with control (Student's t-test).

Involvement of the transport process in ouabain-stimulated $I^{3} \mathrm{H}$ thymidine incorporation

FCS alone stimulated $\left[{ }^{3} \mathrm{H}\right]$ thymidine incorporation into DNA, but the degree was less than that of ouabain stimulation (Fig. 5). Ouabain stimulated $\left[{ }^{3} \mathrm{H}\right]$ thymidine incorporation into DNA even in the presence of FCS (Fig. 5). The effects of ouabain and FCS on $\left[{ }^{3} \mathrm{H}\right]$ thymidine

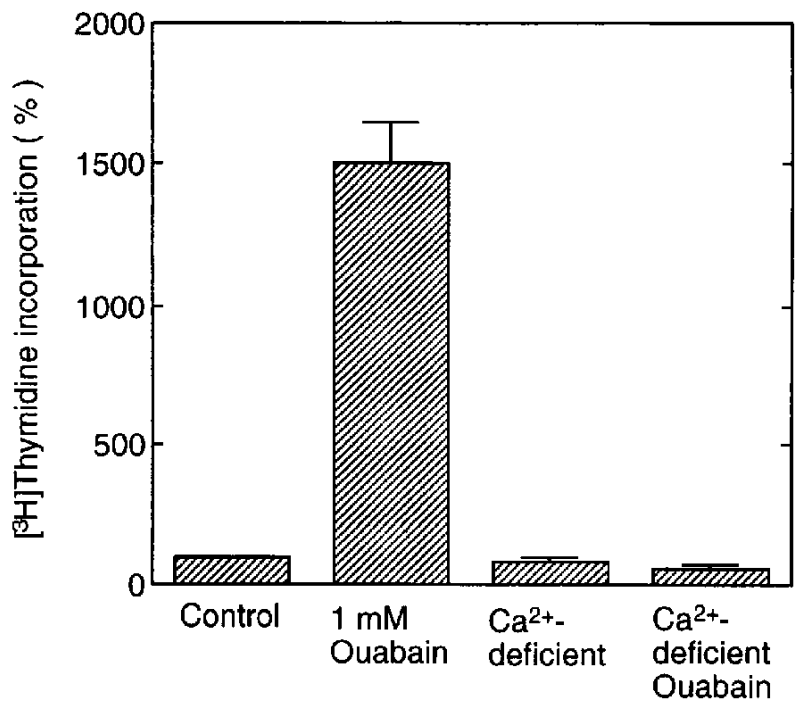

Fig. 7. Effect of extracellular $\mathrm{Ca}^{2+}$ on ouabain-stimulated $\left[{ }^{3} \mathrm{H}\right]-$ thymidine incorporation into astrocytes. The cells were incubated with $1 \mathrm{mM}$ ouabain in the presence and absence of extracellular $\mathrm{Ca}^{2+}$ in FCS-free MEM for $48 \mathrm{hr}$. Results are means \pm S.E.M. of 18 wells. 


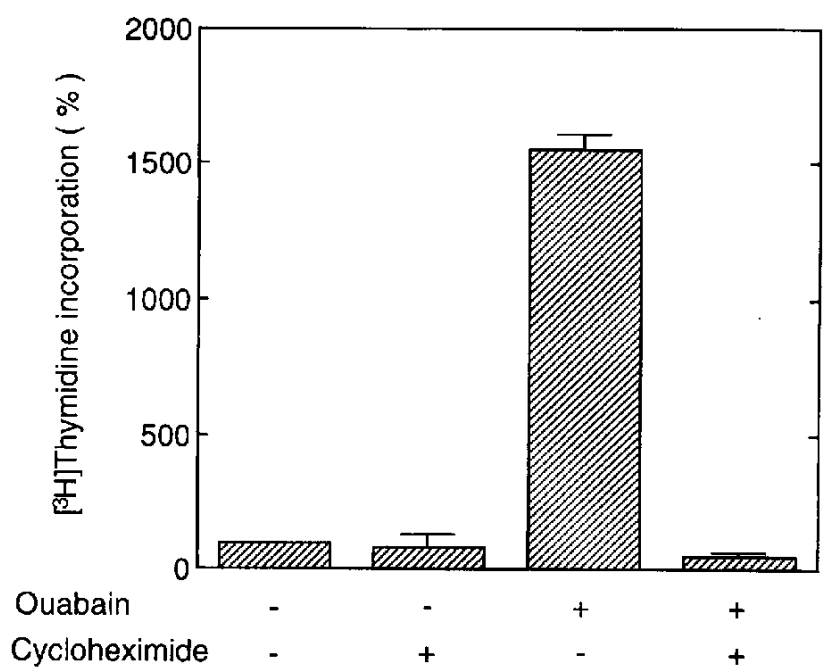

Fig. 8. Effect of cycloheximide on ouabain-stimulated $\left[{ }^{3} \mathrm{H}\right]$ thymidine incorporation into astrocytes. The cells were incubated with 1 $\mathrm{mM}$ ouabain in the absence and presence of $1 \mu \mathrm{M}$ cycloheximide in FCS-free MEM for $48 \mathrm{hr}$. Results are means \pm S.E.M. of 12-13 wells.

incorporation into DNA were examined under conditions that would eliminate the uptake process: the cells were preloaded with $\left[{ }^{3} \mathrm{H}\right]$ thymidine, washed, and treated with ouabain or FCS (Fig. 6). Under the conditions, ouabain and FCS stimulated $\left[{ }^{3} \mathrm{H}\right]$ thymidine incorporation into DNA to the similar degree.

\section{Mechanism for the effect of ouabain}

The effect of ouabain on $\left[{ }^{3} \mathrm{H}\right]$ thymidine incorporation into DNA was not observed in $\mathrm{Ca}^{2+}$-free medium (Fig. 7). The protein synthesis inhibitor cycloheximide, which alone did not affect cell viability (14), blocked ouabaininduced stimulation of $\left[{ }^{3} \mathrm{H}\right]$ thymidine incorporation into DNA (Fig. 8).

\section{DISCUSSION}

The present study shows that ouabain stimulates $\left[{ }^{3} \mathrm{H}\right]$ thymidine incorporation into DNA with an increase in cell number in cultured astrocytes (Figs. 1 and 3 ). Although the effects were observed at the relatively high concentrations of ouabain, the stimulation of DNA synthesis was blocked by excess external $\mathrm{K}^{+}$and mimicked by low external $\mathrm{K}^{+}$(Fig. 2). We have shown that there are two isoforms $\left(\alpha_{1}\right.$ and $\left.\alpha_{2}\right)$ of the $\mathrm{Na}^{+}, \mathrm{K}^{+}$-ATPase in cultured astroyctes, and the major isoform $\alpha_{1}$ is insensitive to ouabain inhibition (14). These observations suggest that the effect of ouabain is due to its binding to the $\alpha_{1}$ isoform of the $\mathrm{Na}^{+}, \mathrm{K}^{+}$-ATPase in the plasma membranes, and the reduced enzyme activity is responsible for the stimulation of DNA synthesis. The bell-shaped dose- response curve had two obvious components: DNA synthesis increased in response to lower concentrations of ouabain, while it gradually decreased in response to higher concentrations of the agent, probably due to a toxic effect (Fig. 1). Pettmann et al. (19) reported that gangliosides stimulated astrocyte DNA synthesis with a dose-response curve similar to that of ouabain. They found that the GM1-induced progressive reduction in cell-subsratum adhesion and the cells could be readily washed off the culture wells. However, it was unlikely that the inhibitory effect of ouabain on DNA synthesis might be due to removal of the cells, since ouabain at 10 $\mathrm{mM}$ did not decrease protein content in astrocytes (data not shown).

Ouabain also stimulated RNA synthesis in astrocytes, but the effect on RNA synthesis was a little different from that on DNA synthesis. The difference in dose-response curve (Fig. 1A) suggests that RNA synthesis is more resistant to ouabain toxicity than DNA synthesis, but the details are not known. It appears that the difference in time course between DNA and RNA syntheses (Fig. 1B) reflects the cell cycle: RNA synthesis starts at the G1 phase, while DNA synthesis occurs at the $\mathrm{S}$ phase.

The present study showed that the stimulation of $\left[{ }^{3} \mathrm{H}\right]-$ thymidine incorporation into DNA was accompanied with an increase in cell number in astrocytes (Fig. 3). This suggests that treatment of astrocytes with ouabain causes cell proliferation. However, the degree of the stimulation was much higher than that of the increase in cell number (Figs. 1 and 3). The large disparity in the results between these two assays may be explained by the possible contribution of the $\left[{ }^{3} \mathrm{H}\right]$ thymidine uptake process to $\left[{ }^{3} \mathrm{H}\right]$ thymidine incorporation, in view of the previous observation that ouabain has direct membrane effects (20). In this experiment, astrocytes were incubated with $\left[{ }^{3} \mathrm{H}\right]$ thymidine before exposure to ouabain to eliminate the effect on the $\left[{ }^{3} \mathrm{H}\right]$ thymidine-uptake process. We found that ouabain caused only a twofold stimulation of $\left[{ }^{3} \mathrm{H}\right]$ thymidine incorporation into DNA in the preloaded astrocytes (Fig. 6). The finding suggests that ouabain increases not only DNA synthesis but also thymidine uptake into the cells. We observed the stimulatory effect by ouabain on DNA synthesis in astrocytes and the inhibitory effect in C6 glioma and fibroblast cells (Fig. 4). The similar stimulation was reported in embryonic neural retina cells (21), but not in other cells $(22,23)$. A slight contamination with micorglia in the astrocyte preparation was considered, but it is not known whether ouabain affects microglial proliferation. These observations suggest that the effect of ouabain on DNA synthesis is specific for some types of cells. The cell-specificity may be explained by differences in the $\mathrm{Na}^{+}, \mathrm{K}^{+}$-ATPase heterogeneity among cells, but the details are not known. 
The mechanism for ouabain-induced cell proliferation is not known. Rayson $(24,25)$ reported that $\mathrm{Ca}^{2+}$ plays an important role in ouabain-induced up-regulation of $\mathrm{Na}^{+}, \mathrm{K}^{+}$-ATPase in rat outer medullary tubule preparation. We found that ouabain-stimulated DNA synthesis in astrocytes was dependent on $\mathrm{Ca}^{2+}$ (Fig. 7) and blocked by the protein synthesis inhibitor cycloheximide (Fig. 8). In a separate experiment, we have found that ouabain increases the levels of the $\mathrm{Na}^{+}, \mathrm{K}^{+}$-ATPase $\alpha_{1}$ and $\beta_{1}$ mRNAs and proteins in cultured astrocytes (unpublished). These findings imply that the enzyme may be a candidate for the newly synthesized protein responsible for ouabain-induced cell proliferation.

Ouabain injected into specific brain regions stimulates the release of neurotransmitters (26-28). This effect may be involved in ouabain-induced brain damage (11-13, 29) or ouabain-induced sympathetic response $(7,8)$, but the details are not known. The present finding that ouabain has biphasic effects on astrocyte proliferation depending on the concentration implies that astrocytes may play a role in the in vivo effects of ouabain. It should be noted that the biphasic effect of ouabain on DNA synthesis was similar to that of ganglioside in cultured astrocytes $(19,30)$, which had a protective effect against ischemic brain damage $(31,32)$. Further studies are required to clarify the possible role of astrocytes in the in vivo effects of ouabain.

\section{Acknowledgments}

This study was supported by grants from the Ministry of Education, Science, Sports and Culture of Japan, and Sumitomo Pharmaceuticals Co., Ltd.

\section{REFERENCES}

1 Hamlyn JM and Manunta P: Ouabain, digitalis-like factors and hypertension. J Hypertens Supp 10, S99-S111 (1992)

2 Yamada $H$, Naruse $M$, Naruse $K$, Demura $H$, Takahashi $H$, Yoshimura $\mathrm{M}$ and Ochi $\mathrm{J}$ : Histological study on ouabain immunoreactivities in the mammalian hypothalamus. Neurosci Lett 141, 143-146 (1992)

3 Leenen FH, Harmsen E, Yu $\mathbf{H}$ and Ou C: Effects of dietary sodium on central and peripheral ouabain-like activity in spontaneously hypertensive rats. Am J Physiol 264, H2051-H2055 (1993)

4 Leenen FH, Huang BS and Harmsen E: Role of brain ouabainlike activity in the central effects of sodium in rats. J Cardiovasc Pharmacol 22, S72-S74 (1993)

5 Lichtstein D, Samuclov S, Gati I and Wechter WJ: Digitalis-like compounds in animal tissues. J Basic Clin Physiol Pharmacol 3, $269-292(1992)$

6 Yamada K, Goto A, Nagoshi H, Hui C and Omata M: Role of brain ouabain-like compound in central nervous systemmediated natriuresis in rats. Hypertension 23, 1027-1031 (1994)

7 Huang BS, Huang X, Harmsen E and Leenen FH: Chronic central versus peripheral ouabain, blood pressure, and sym- pathetic activity in rats. Hypertension 23, $1087-1090$ (1994)

8 Iyoda I, Takahashi H, Lee LC, Okajima H, Inoue A, Sasaki S, Takeda K, Yoshimura $\mathrm{M}$ and Ijichi $\mathrm{H}$ : Cardiovascular and sympathetic responses to ouabain injected into the hypothalamus in rats. Cardiovasc Res 20, 294-298 (1986)

9 Jacomini LC, Elghozi JL, Dagher G, Devynck MA and Meyer $P$ : Central hypertensive effect of ouabain in rats. Arch Int Pharmacodyn Ther 267, 310-318 (1984)

10 Jones DL and Lo S: Ouabain injected into the hypothalamus elicits pressor responses in anaesthetized rats: a mapping study. Pharmacol Biochem Behav 36, 979-983 (1990)

11 Lees GJ, Lehmann A, Sandberg $M$ and Hamberger A: The neurotoxicity of ouabain, a sodium-potassium ATPase inhibitor, in the rat hippocampus. Neurosci Lett 120, 159-162 (1990)

12 Lees GJ and Leong W: Brain lesions induced by specific and non-specific inhibitors of sodium-potassium ATPase. Brain Res 649, $225-233$ (1994)

13 Lees GJ and Leong W: The sodium-potassium ATPase inhibitor ouabain is neurotoxic in the rat substantia nigra and striatum. Neurosci Lett 188, 113-116 (1995)

14 Matsuda T, Murata Y, Kawamura N, Hayashi M, Tamada K, Takuma K, Maeda S and Baba A: Selective induction of $\alpha 1$ isoform of $\left(\mathrm{Na}^{+}+\mathrm{K}^{+}\right)$-ATPase by insulin/insulin-like growth factor-I in cultured rat astrocytes. Arch Biochem Biophys 307, $175-182$ (1993)

15 Matsuda T, Murata Y, Tanaka K, Hosoi R, Hayashi M, Tamada $\mathrm{K}$, Takuma $\mathrm{K}$ and Baba $\mathrm{A}$ : Involvement of $\mathrm{Na}^{+}, \mathrm{K}^{-}$-ATPase in the mitogenic effect of insulin-like growth factor-I on cultured rat astrocytes. J Neurochem 66, 511-516 (1996)

16 Takuma K, Matsuda T, Hashimoto H, Asano S and Baba A: Cultured rat astrocytes possess $\mathrm{Na}^{+}-\mathrm{Ca}^{2-}$ exchanger. Glia 12, 336-342 (1994)

17 Han VK, Lauder JM and D'Ercole AJ: Characterization of somatomedin/insulin-like growth factor receptors and correlation with biologic action in cultured neonatal rat astroglial cells. J Neurosci 7, 501-511 (1987)

18 Kitanaka J, Hashimoto H, Gotoh M, Mayumi T and Baba A: Mechanism of extracellular ATP-stimulated phosphoinositide hydrolysis in rat glioma C6 cells. J Pharmacol Exp Ther 263, 1248- 1252 (1992)

19 Pettmann B, Manthorpe M and Varon S: Ganglioside GM1 actions on cell-substratum adhesion and DNA synthesis by cultured astroglial cells. J Neurosci Res 20, 442-450 (1988)

20 Curtis DR: Ouabain and the membrane transport of amino acids and amines. Neurochem Res 12, 755-757 (1987)

21 Kaplowitz PB and Moscona AA: Stimulation of DNA synthesis by ouabain and concanavalin $A$ in cultures of embryonic neural retina cells. Cell Differ 5, $109-119$ (1976)

22 Shank BB and Smith NE: Regulation of cellular growth by sodium pump activity. J Cell Physiol 87, 377-387 (1976)

23 Szamel M, Somogyi J, Csukas I and Solymosy F: Effect of ouabain on macromolecular synthesis during the cell cycle in mitogen-stimulated human lymphocytes. Biochim Biophys Acta 633, 347-360 (1980)

24 Rayson BM: $\left[\mathrm{Ca}^{2+}\right]_{\mathrm{i}}$ regulates transcription rate of the $\mathrm{Na}^{+} /$ $\mathrm{K}^{1}$-ATPase alpha 1 subunit. J Biol Chem 266, 21335-21338 (1991)

25 Rayson BM: Calcium: a mediator of the cellular response to chronic $\mathrm{Na}^{+} / \mathrm{K}^{\cdots}$-ATPase inhibition. J Biol Chem 268, $8851-8854$ (1993) 
26 Fairbrother IS, Arbuthnott GW, Kelly JS and Butcher SP: In vivo mechanisms underlying dopamine release from rat nigrostriatal terminals: I. Studies using veratrine and ouabain. J Neurochem 54, 1834 - 1843 (1990)

27 Jacobson I, Hagberg H, Sandberg $M$ and Hamberger A: Ouabain-induced changes in extracellular aspartate, glutamate and GABA levels in the rabbit olfactory bulb in vivo. Neurosci Lett 64, 211-215 (1986)

28 Westerink BH, Damsma G and de Vries JB: Effect of ouabain applied by intrastriatal microdialysis on the in vivo release of dopamine, acetylcholine, and amino acids in the brain of conscious rats. J Neurochem 52, 705-712 (1989)

29 Bagetta G, Iannone M, Palma E, Rodino P, Granato T and Nistico G: Lack of involvement of nitric oxide in the mecha- nisms of seizures and hippocampal damage produced by kainate and ouabain in rats. Neurodegeneration 4, 43-49 (1995)

30 Katoh Semba R, Facci L, Skaper SD and Varon S: Gangliosides stimulate astroglial cell proliferation in the absence of serum. $J$ Cell Physiol 126, 147-153 (1986)

31 Lipartiti M, Lazzaro A, Zanoni R, Bonvento $G$ and Mazzari S: Effects of monosialoganglioside GM1 in experimental models of ischemic brain damage. Ital J Neurol Sci 12, 11-13 (1991)

32 Mahadik SP, Bharucha VA, Stadlin A, Ortiz A and Karpiak SE: Loss and recovery of activities of $\alpha+$ and $\alpha$ isozymes of $\left(\mathrm{Na}^{+}+\mathrm{K}^{+}\right)$-ATPase in cortical focal ischemia: GMl ganglioside protects plasma membrane structure and function. J Neurosci Res 32, 209-220 (1992) 